\title{
IMPLEMENTASI MULTIMEDIA I-SPRING DENGAN POWERPOINT UNTUK MENINGKATKAN HASIL BELAJAR PADA PEMBELAJARAN SALAT UNTUK MATA PELAJARAN PENDIDIKAN AGAMA ISLAM
}

\section{IMPLEMENTATION OF I-SPRING MULTIMEDIA WITH POWERPOINT TO IMPROVE LEARNING OUTCOMES IN PRAYING LEARNING FOR ISLAMIC RELIGIOUS EDUCATION LEARNING}

\author{
Irwanto \\ Pendidikan Vokasional Teknik Elektro, FKIP, Universitas Sultan Ageng Tirtayasa \\ irwanto.ir@untirta.ac.id
}

Pengutipan: Irwanto. (2020). Implementasi multimedia i-spring dengan powerpoint untuk meningkatkan hasil belajar pada pembelajaran salat untuk mata pelajaran pendidikan agama Islam. Pedagogi: Jurnal Penelitian Pendidikan, 7 (1), hlm 65-78.

Diajukan: 15-05-2020Ｄiterima: 27-05-2020Ｄiterbitkan: 31-05-2020

\begin{abstract}
ABSTRAK
Capaian hasil belajar mata pelajaran Pendidikan Agama Islam kurang dari KKM yang ditentukan. Tujuan utama penelitian ini adalah untuk mengetahui ada atau tidak adanya perbedaan peningkatan hasil belajar pendidikan agama Islam mengenai materi tata cara shalat. Metode yang digunakan dalam penelitian ini adalah eksperimen kuantitatif. Populasi penelitian ini adalah siswa kelas IV SDN Jambu dengan sampel 26 orang dan SDN Kampung Baru dengan sampel 26 orang. Hasil penelitian yang didapat adalah 1) terdapat peningkatan hasil belajar pada kelompok eksperimen jika dilihat dari peningkatan rata-rata hasil belajar siswa, 2) terdapat peningkatan hasil belajar pada kelompok kontrol jika dilihat dari peningkatan rata-rata hasil belajar siswa, dan 3) tidak terdapat perbedaan hasil belajar antara kelompok eksperimen yang menggunakan multimedia iSpring dengan kelompok kontrol yang menggunakan PowerPoint. Dengan adanya media yang digunakan dalam pembelajaran, maka hasil belajar siswa pun mengalami peningkatan.
\end{abstract}

Kata Kunci: implementasi; multimedia iSpring; PowerPoint; hasil belajar

\section{ABSTRACT}

The learning outcomes of Islamic Religious Education subjects were less than the specified $K K M$. The main objective of this research was to find out whether or not there is a difference in the improvement of Islamic religious education learning outcomes regarding the matter of procedures for prayer. The method used in this study is a quantitative experiment. The population of this research is the fourth grade students of Jambu SDN with a sample of 26 people and SDN Kampung Baru with a sample of 26 people. The results obtained were 1) there is an increase in learning outcomes in the experimental group when viewed from an increase in average student learning outcomes, 2) there is an increase in learning outcomes in the control group when seen from an increase in average student learning outcomes, and 3 ) there is no difference in learning outcomes between the experimental group using iSpring 
Irwanto

IMPLEMENTASI MULTIMEDIA I-SPRING DENGAN POWERPOINT UNTUK

MENINGKATKAN HASIL BELAJAR PADA PEMBELAJARAN SALAT UNTUK MATA

PELAJARAN PENDIDIKAN AGAMA ISLAM

multimedia with the control group using PowerPoint. With the media used in learning, student learning outcomes have also increased.

Keywords: implementation; iSpring multimedia; PowerPoint; learning outcomes 


\section{PENDAHULUAN}

Undang-undang Nomor 20 tahun 2003 tentang Sistem Pendidikan Nasional memiliki visi mewujudkan sistem pendidikan sebagai pranata sosial yang kuat dan berwibawa untuk memberdayakan semua warga negara Indonesia agar menjadi manusia yang berkualitas sehingga mampu berperan aktif dalam melewati tantangan zaman yang selalu berubah.Pendidikan menjadi salah satu sektor yang sangat penting dalam pengembangan sumber daya manusia. Berbagai pembaharuan dilakukan untuk meningkatkan kualitas pendidikan seperti pembaharuan kurikulum, perubahan sistem penilaian, pengembangan pendekatan dan model pembelajaran, pembaharuan metode belajar serta media pembelajaran. Dimulai dari tingkatan Sekolah Dasar, kualitas pendidikan harus diperbaiki. Pemberian konsep harus diberikan secara benar pada tingkatan SD, seperti pada mata pelajaran Pendidikan Agama Islam (PAI).

PAI di tingkat Sekolah Dasar hakikatnya memberikan pengalaman belajar terhadap anak dalam hal melaksanakan tata cara shalat sesuai dengan tahapan perkembangan. PAI SD dikatakan sebagai pondasi belajar untuk jenjang yang lebih tinggi sehingga penting untuk diperhatikan, yang kemudian diharapkan akan terjadi peningkatan prestasi belajar PAI. Faktanya saat ini PAI manjadi salah satu pelajaran yang kurang disukai oleh siswa karena hanya penyampaian materinya selalu monoton dan metodenya ceramah. Konsep PAI merupakan konsep yang nyata dalam kehidupan sehari-hari, terlebih lagi KD melaksanakan shalat. Sementara pola pikir siswa SD berada pada tahap operasional kongkrit. Siswa perlu diupayakan untuk memahami agama sesuai dengan tingkat perkembangannya masingmasing.

Cara mengajar guru yang demikian mengakibatkan rendahnya prestasi belajar PAI siswa kelas III SD. Banyak faktor yang mempengaruhi prestasi belajar PAI, seperti sikap tanggung jawab dalam belajar masih kurang diaplikasikan. Berdasarkan pengamatan, banyak siswa bermain sendiri, sebagian besar siswa cenderung kurang aktif dalam mengikuti pelajaran, dan keberanian siswa mengerjakan shalat masih kurang. Siswa cenderung mengabaikan tugas jika kurang mendapatkan pengawasan guru dan terkadang ada yang tidak mengerjakan PR PAI yang diberikan oleh guru. Hal ini menunjukkan kurangnya kesadaran seperti tanggung jawab dan dorongan dalam diri siswa sendiri untuk dapat mencapai prestasi yang lebih baik.

Proses pembelajaran yang efektif, menyenangkan, menarik, dan bermakna bagi siswa dipengaruhi oleh berbagai unsur antara lain guru yang memahami secara utuh hakekat, sifat, dan karakteristik siswa, metode pembelajaran yang berpusat pada kegiatan siswa, sarana belajar siswa yang memadai, tersedianya berbagai sumber belajar dan media yang menarik yang mampu mendorong siswa untuk belajar. Secara khusus, tersedianya berbagai sumber belajar akan mendukung terhadap penciptaan kondisi belajar siswa yang menarik dan menyenangkan. Salah satu sumber belajar tersebut adalah media pembelajaran. Media pembelajaran harus di manfaatkan secara maksimal untuk membantu pebelajar mencapai tujuan belajarnya, pemanfaatan media dimaksudkan untuk membantu agar kegiatanpembelajaran lebih efektif mencapai tujuan dan efisien dalam hal tenaga, waktu dan biaya.

Media pembelajaran yang dirancang dengan baik akan sangat membantu siswa mencapai tujuan pembelajaran. Tiap media pembelajaran memiliki karakteristik masingmasing, maka perlu adanya perencanaan yang sistematis untuk penggunaan media pembelajaran. Seperti dengan memadukan media tersebut dengan metode pembelajaran yang sesuai salah satunya yang dapat dilakukan adalah dengan mengembangkan kemampuan psikomotorik para siswa di SD dengan memberikan pengajaran berbasis multimedia atau pembelajaran berbasis masalah sehingga dengan metode ini diharapkan siswa akan semakin paham dan lebih dekat dengan metode yang digunakan dalam kehidupan sehari-hari serta 
Irwanto

IMPLEMENTASI MULTIMEDIA I-SPRING DENGAN POWERPOINT UNTUK

MENINGKATKAN HASIL BELAJAR PADA PEMBELAJARAN SALAT UNTUK MATA

PELAJARAN PENDIDIKAN AGAMA ISLAM

memberikan pemahaman yang mendalam dalam menghadapi permasalahan seperti yang akan dihapai dalam kehidupan yang nyata sekarang ini.

Kendala dalam proses pembelajaran PAI, terlihat masih kurang persiapan siswa, buku paket yang masih terbatas, guru mengalami kesulitan dalam mengajarkan PAI, serta masih belum bisa menggunakan teknologi karena dari SDM masih belum menguasai, selain itu belum ada multimedia yang sesuai untuk mengajarkan PAI di sekolah. Guru mengalami kesulitan dalam mengembangkan multimedia pada pembelajaran PAI pada hal guru membutuhkan multimedia yang valid dan dapat digunakan untuk mengajarkan PAI dan belum diketahui keefektifan penggunaan multimedia pembelajaran PAI oleh guru, sehingga antusias siswa masih rendah karena proses pembelajaran yang cenderung membosankan. Jika kondisi tersebut dibiarkan, maka menimbulkan dampak yang kurang baik bagi sekolah.

Dari permasalahan di atas sangat diperlukan atau perkembangan media belajar untuk pembelajaran PAI yang dapat meningkatkan hasil belajar serta penggunaan multimedia dalam pembelajaran PAI yang dihasilkan tersebut efektif untuk meningkatkan hasil belajar PAI. Harapannya adalah membantu meningkatkan pemahaman siswa terhadap materi shalat, menyediakan pengalaman belajar yang efektif sekaligus menyenangkan, memotivasi siswa untuk belajar PAI dengan cara yang baru, memotivasi siswa untuk menggunakan multimedia sebagai sarana untuk mempelajari PAI dan memotivasi guru untuk mengembangkan multimedia berbantuan komputer sebagai sarana belajar. Menurut Daryanto (2010) belajar adalah suatu proses usaha yang dilakukan seseorang untuk memperoleh suatu perubahan tingkah laku yang baru secara keseluruhan, sebagai hasil pengalamannya sendiri dalam interaksi dengan lingkungannya. Selanjutnya Suyono \& Hariyanto (2016) mengartikan belajar sebagai suatu aktivitas atau suatu proses dalam rangka mendapatkan pengetahuan, meningkatkan keterampilan, memperbaiki perilaku, sikap, serta memperkokoh kepribadian. Gagne dalam Suyono \& Hariyanto (2016) mendefinisikan belajar sebagai sebuah proses perubahan tingkah laku manusia yang mencakup perubahan kecenderungan seperti minat, nilai, atau sikap serta perubahan kemampuannya, yaitu peningkatan kemampuan untuk melakukan berbagai macam kinerja. Sejalan dengan definisi belajar tersebut, Gagne, Divesta \& Thompson dalam Suyono \& Hariyanto (2016) menyatakan belajar sebagai perubahan tingkah laku yang relatif menetap sebagai hasil dari pengalaman.

Lebih lanjut Dimyati \& Mudjiono (2006) mendefinisikan belajar sebagai kegiatan individu dalam mendapatkan pengetahuan, perilaku serta keterampilan dengan cara mengolah bahan belajar. Dalam kegiatan belajar tersebut individu mengalami perubahan dalam ranahranah kognitif, afektif, dan psikomotor. Siregar \& Nara (2010) mendeskripsikan belajar sebagai suatu aktifitas mental (psikis) yang berlangsung dalam interaksi dengan lingkungannya sehingga menghasilkan perubahan yang bersifat relatif tetap. Adapun ciri-ciri belajar menurut Siregar \& Nara (2010) yaitu: (1) Adanya perubahan ditandai dengan adanya kemampuan baru. Perubahan tersebut bersifat pengetahuan (kognitif), nilai dan sikap (afektif), ataupun keterampilan (psikomotor). (2) Perubahan tersebut bersifat tetap atau dapat disimpan, tidak berlangsung hanya sesaat saja. (3) Perubahan tersebut harus dilakukan dengan mengadakan usaha, tidak terjadi begitu saja. Perubahan akan terjadi akibat adanya interaksi yang berlangsung dengan lingkungan. (4) Perubahan tersebut tidak hanya diakibatkan oleh kedewasaan, penyakit, tidak akibat kelelahan, pengaruh obat-obatan ataupun pertumbuhan fisik.

Belajar merupakan sebuah wujud diri untuk dapat mengenal sesuatu yang sedang dipelajari dan dibaca secara lebih terperinci dan serius sehingga terdapat sesuatu yang substansial yang bisa didapatkan. Dalam kegiatan belajar terdapat sebuah proses berpikir kritis yang secara terus-menerus dilakukan dengan serius dan tegas. Dengan belajar 
sedemikian rupa, maka akan diperoleh makna yang benar-benar baru, belajar tidak semata dilakukan hanya untuk mendapatkan hal-hal baru, melainkan adalah sebuah kegiatan dinamis dan progresif yang dapat membangkitkan cara pandang dan pikir yang berbeda (Yamin, 2015).

Berdasarkan beberapa pendapat diatas dapat disimpulkan bahwa belajar adalah suatu aktivitas atau suatu proses untuk memperoleh kecakapan, keterampilan, pengetahuan, pemahaman, kebiasaan dan sikap. Sehingga dapat mengetahui suatu hal baru serta dapat meningkatkan pengetahuannya, mengubah dari yang tidak tahu menjadi tahu, dari yang tidak bisa menjadi bisa, dan dari yang tidak baik menjadi baik.

Dalam proses belajar terdapat suatu tujuan tertentu yang hendak dicapai, ada beberapa hal yang menjadi tujuan dalam belajar. Klasifikasi hasil belajar menurut Benyamin Bloom dalam Nana Sudjana (2010) yaitu: (a) Ranah kognitif, berkaitan dengan hasil belajar intelektual yang terdiri dari enam butir aspek yang meliputi pengetahuan, pemahaman, aplikasi, analisis, sintesis, dan evaluasi. (b) Ranah afektif, berkaitan dengan sikap dan nilai yang terdiri dari lima butir aspek yang meliputi penerimaan, jawaban, penilaian, organisasi, dan internalisasi. (c) Ranah psikomotorik, berkaitan dengan hasil belajar berupa ketrampilan serta kemampuan bertindak, meliputi enam butir aspek yaitu gerakan refleks, keterampilan gerak dasar, kemampuan perseptual, ketepatan, keterampilan kompleks, dan gerakan ekspresif dan interpretatif.

Bagi setiap orang, belajar dapat dilakukan dengan banyak cara yang beda. Belajar dapat dilakukan dengan cara menemukan, melihat dan juga meniru. Melalui belajar tersebut seseorang akan dapat mengalami perubahan serta pertumbuhan didalam dirinya baik itu secara fisik maupun psikis. Perubahan secara fisik apabila yang dipelajari berkaitan dengan ranah psikomotor. Perubahan psikis apabila yang dipelajari berkenaan dengan ranah afektif. Perubahan pengetahuan apabila yang dipelajari berupa dalam ranah kognitif. Maka pada hakikatnya belajar pada ranah kognitif juga akan bersinggungan dengan ranah afektif dan juga dengan ranah psikomotorik. Ketiga ranah ini saling berhubungan antara satu dengan yang lainnya.

Definisi dari pembelajaran tidak terlepas dari pengertian belajar, belajar dan pembelajaran menjadi suatu rangkaian kegiatan yang tidak dapat dipisahkan. Hasil dari belajar dapat menjadi acuan model pembelajaran dalam proses kegiatan pembelajaran selanjutnya. Pembelajaran dalam Undang-undang nomor 20 tahun 2003 tentang Sistem Pendidikan Nasional diartikan sebagai proses interaksi antara peserta didik dengan pendidik dan sumber belajar pada suatu lingkungan belajar. Sejalan dengan definisi pembelajaran tersebut, Syaiful Sagala (2012) mendefinisikan pembelajaran sebagai suatu proses komunikasi dua arah, mengajar dilakukan oleh guru sebagai pendidik, sedangkan belajar dilakukan oleh peserta didik atau siswa.

Dimyati \& Mudjiono (2006) mengemukakan bahwa pembelajaran adalah kegiatan pendidik secara terprogram dalam desain instruksional, untuk membuat siswa belajar secara aktif, yang menekankan pada penyediaan sumber belajar. Hal ini sependapat dengan Heri Rahyubi (2016) yang mengartikan pembelajaran sebagai suatu proses interaksi peserta didik dengan pendidik serta sumber belajar pada suatu lingkungan belajar, pendidik dalam kegiatan pembelajaran memberikan batuan agar dapat terjadi proses pemerolehan ilmu dan pengetahuan, pembentukan sikap dan kepercayaan, serta kemampuan dan kemahiran peserta didik. Konsep pembelajaran menurut Rusman (2012) adalah suatu proses interaksi yang dilakukan antara pendidik dengan peserta didik, baik interaksi secara langsung seperti dalam kegiatan tatap muka ataupun secara tidak langsung, yaitu dengan menggunakan perantara media pembelajaran. Dengan didasari oleh adanya perbedaan interaksi dalam pembelajar tersebut, maka kegiatan pembelajaran bisa dilakukan dengan menggunakan berbagai macam pola. 
Irwanto

IMPLEMENTASI MULTIMEDIA I-SPRING DENGAN POWERPOINT UNTUK

MENINGKATKAN HASIL BELAJAR PADA PEMBELAJARAN SALAT UNTUK MATA

PELAJARAN PENDIDIKAN AGAMA ISLAM

Oemar Hamalik (2011) menjelaskan bahwa pembelajaran adalah suatu kombinasi yang tertata meliputi unsur-unsur material, fasilitas dan perlengkapan, manusia, serta prosedur yang saling mempengaruhi hingga mencapai tujuan pembelajaran yang ditetapkan. Unsur material, meliputi gambar, buku bacaan atau buku tulis, slide presentasi, video dan audio. Unsur fasilitas dan perlengkapan, meliputi ruangan kelas, papan tulis, komputer dan perlengkapan audio visual. Unsur manusia yang terlibat dalam sistem pembelajaran terdiri dari guru, siswa dan tenaga lainnya, misalnya tenaga laboratorium atau perpustakaan. Unsur prosedur meliputi cara belajar, praktik, jadwal, ujian, cara penyampaian informasi dan lain sebagainya. Sistem pembelajaran dapat dilaksanakan dengan metode praktik, membaca buku, belajar dikelas, observasi, atau di luar sekolah diwarnai oleh organisasi dan interaksi antara berbagai komponen yang saling berkaitan, untuk pembelajaran peserta didik.

Berdasarkan beberapa pendapat diatas maka pembelajaran dapat didefinisikan sebagai suatu proses dimana adanya interaksi antara peserta didik dengan pendidik yang menghasilkan respon tertentu dan berjalan secara komunikatif antar dua arah yang gunanya untuk saling bertukar informasi. Pembelajaran merupakan sebuah sistem, yang terdiri atas berbagai macam komponen yang saling berhubungan antara satu dengan yang lainnya. Komponen tersebut meliputi; materi, media, tujuan, metode, dan evaluasi. Semua komponen pembelajaran tersebut perlu diperhatikan oleh pendidik dalam memilih dan menentukan materi, media, metode, strategi dan pendekatan apa yang paling tepat untuk diimplementasikan dalam kegiatan pembelajaran.

Tanpa adanya dukungan dari komponen-komponen pembelajaran tersebut maka kegiatan pembelajaran tidak akan berjalan dengan lancar, karena antara komponen pembelajaran dengan proses pembelajaran saling berkaitan dan membutuhkan. Kegiatan pembelajaran sangat penting keberadaanya karena dengan pembelajaran diharapkan terjadi perubahan perilaku peserta didik ke arah yang lebih positif dan diharapkan dengan adanya proses belajar mengajar akan terjadi perubahan tingkah laku pada peserta didik.

Yudhi Munadi (2010) menjelaskan kata media berasal dari bahasa latin, yakni 'medius' yang secara harifahnya berarti 'tengah', 'pengantar' atau 'perantara'. Dalam bahasa arab media disebut 'wasal' bentuk jama' dari 'wasailah' yakni sinonim 'al-wasth' yang artinya juga 'tengah'. Kata 'tengah' itu sendiri diartikan berada diantara dua buah sisi, maka dapat disebut juga sebagai 'perantara' (wasilah) yang mengantarai kedua buah sisi tersebut. Karena letaknya berada di tengah ia juga bisa disebut sebagai penghubung atau pengantar, yaitu yang menghubungkan atau menghantarkan atau menyalurkan sesuatu hal dari suatu sisi ke sisi lainnya. Sedangkan media pembelajaran didefinisikan oleh Yudhi Munadi (2010) sebagai sumber-sumber pembalajaran selain guru, yang memiliki fungsi sebagai penyalur atau penghubung informasi yang diadakan atau diciptakan secara terencana oleh guru atau pendidik.

Azhar Arsyad (2017) mendeskripsikan media pembelajaran sebagai segala sesuatu yang bisa dipergunakan untuk menyampaikan informasi atau pesan dalam proses pembelajaran sehingga dapat merangsang minat serta perhatian peserta didik dalam belajar. Sedangkan Rusman (2012) mengartikan media pembelajaran sebagai alat yang memungkinkan peserta didik untuk memahami atau mengerti sesuatu dengan mudah untuk mengingatnya dalam waktu yang relatif lebih lama dibanding dengan penyampaian materi ajar dengan cara ceramah dan tatap muka tanpa alat bantu atau media pembelajaran. Menurut Rudi Susilana \& Cepi Riyana (2008) media pembelajaran selalu terdiri atas dua unsur dasar yang penting, yaitu unsur peralatan atau perangkat keras (hardware) dan unsur pesan yang dibawanya (message/software). Dengan demikian media pembelajaran membutuhkan 
peralatan untuk menyajikan pesan, namun yang terpenting bukanlah peralatan tersebut, melaikan informasi atau pesan belajar yang dibawa oleh media pembelajaran tersebut.

Berdasarkan berbagai definisi media pembelajaran diatas, dapat disimpulkan bahwa media pembelajaran merupakan segala sesuatu yang secara fisik atau permodelan digunakan untuk penyampaian informasi atau materi pembelajaran sehingga terjadi interaksi transfer of knowledge antara pendidik dengan peserta didik dalam proses pembelajaran di sekolah yang pada akhirnya diharapkan dapat meningkatkan hasil belajar siswa. Dengan media pembelajaran diharapkan dapat merangsang perasaan, perhatian, pikiran, dan minat serta kemauan peserta didik dalam mengikuti kegiatan pembelajaran.

Media pembelajaran dapat dipahami sebagai sebuah media yang digunakan dalam proses dan tujuan pembelajaran. Pada dasarnya proses pembelajaran juga merupakan komunikasi, maka media pembelajaran bisa diartikan sebagai media komunikasi yang digunakan dalam proses komunikasi tersebut, media pembelajaran memiliki peranan penting sebagai sarana untuk menyalurkan informasi pembelajaran. Tanpa media, informasi pembelajaran sulit tersampaikan dan proses pembelajaran sebagai proses komunikasi juga tidak akan bisa terlaksana secara optimal. Media pembelajaran adalah komponen integral dari sebuah sistem pembelajaran.

Media pembelajaran memiliki karakteristik dan keampuhan masing-masing, oleh karena itu yang diharapkan kepada pendidik agar mampu menentukan media pembelajaran yang digunakan sesuai dengan kebutuhan pada saat melakukan kegiatan belajar mengajar. Harapan pendidik tentu saja agar media pembelajaran menjadi alat bantu yang dapat mempercepat serta mempermudah pencapaian pesan pembelajaran.

Media pembelajaran dalam pembelajaran yang berpusat pada guru berperan untuk mendukung keberadaan guru di dalam kelas. Media pembelajaran didesain untuk mengembangkan dan meningkatkan proses belajar serta mendukung pembelajaran yang efektifitasnya tergantung guru. Kemudian peran media dalam pembelajaran yang berpusat pada siswa, yaitu media pembelajaran akan memberikan kesempatan kepada guru untuk menghabiskan lebih banyak waktu dalam mengidentifikasi dan memperbaiki masalahmasalah pembelajaran, berdialog dengan siswa, berefleksi dan memberikan pendampingan khusus secara individu atau dengan kata lain media justru dapat membantu guru menjadi kreatif dalam memberikan pengalaman belajar yang lebih bermakna bagi siswa dan bukan sekedar penyampaian informasi saja.Jadi bisa dipahami bahwa pembelajaran tidak akan berjalan secara efektif jika tidak ada sbuah media pembelajaran, karena media pembelajaran menjadi salah satu komponen penting dari belajar mengajar. Permasalahan dalam menyampaikan materi pelajaran maupun informasi dalam pembelajaran dapat diatasi dengan menggunakan media tertentu yang tepat sehingga akan membantu tercapainya tujuan pembelajaran.

Fungsi utama media pembelajaran menurut Yudhi Munadi (2010: 36) adalah sebagai sumber belajar, fungsi lainnya merupakan hasil pertimbangan berdasarkan kajian ciri-ciri umum yang dimilikinya. Adapun fungsi lain dari media pembelajaran di uraikan sebagai berikut: (a) Fungsi media pembelajaran sebagai sumber belajar, media pembelajaran memiliki fungsi dasar sebagai sumber belajar. Dalam kalimat 'sumber belajar' ini tersirat makna keaktifan, yakni sebagai penyampai, penghubung, penyalur, dan lain sebagainya. Fungsi media pembelajaran sebagai sumber belajar adalah fungsi dsaranya disamping fungsifungsinya yang lain. (b) Fungsi semantik, fungsi semantik merujuk pada kemampuan media untuk menambah perbendaharaan kata (simbol verbal) yang maknanya benar-benar dipahami pesera didik (tidak verbalistik). (c) Fungsi manipulatif, fungsi manipulatif didasarkan pada ciri umum yang dimiliki media pembelajaran. Berdasarkan ciri umum ini, media pembelajaran memiliki dua kemampuan, yaitu mengatasi batas-batas ruang dan waktu serta mengatasi keterbatasan indrawi. (d) Fungsi psikologis, fungsi psikologis ini dibagi menjadi 
Irwanto

IMPLEMENTASI MULTIMEDIA I-SPRING DENGAN POWERPOINT UNTUK

MENINGKATKAN HASIL BELAJAR PADA PEMBELAJARAN SALAT UNTUK MATA

PELAJARAN PENDIDIKAN AGAMA ISLAM

beberapa fungsi lain, yaitu: (1) Fungsi atensi, media pembelajaran bisa meningkatkan perhatian peserta didik terhadap materi ajar. (2) Fungsi afektif, media pembelajaran dapat menggugah emosi, perasaan, dan tingkat penerimaan atau penolakan siswa terhadap satu hal. (3) Fungsi kognitif, ketika siswa belajar menggunakan suatu media pembelajaran maka siswa tersebut akan memperoleh dan menggunakan bentuk gambaran yang mewakili objek yang dihadapi, baik objek tersebut merupakan manusia, benda, atau peristiwa tertentu. Objek tersebut digambarkan atau dihadirkan dalam diri seseorang melalui gagasan, tanggapan, atau lambang. (4) Fungsi imajinatif, media pembelajaran bisa meningkatkan dan mengembangkan imajinasi siswa. Imajinasi tersebut meliputi penimbulan atau kreasi objek-objek baru sebagai rancangan dimasa mendatang. (5) Fungsi motivasi, dengan media pembelajaran siswa dapat termotivasi dan terdorong untuk melaksanakan kegiatan belajar mengajar sehingga tujuan pembelajaran dapat tercapai. (6) Fungsi sosio-kultural, Fungsi media sosio-kultural, yakni dapat mengatasi hambatan perbedaan yang ada diantara peserta didik.

Sadiman(2010) menjelaskan secara umum media pembelajaran mempunyai kegunaan sebagai berikut: (a) Memperjelas penyampaian informasi agar tidak terlalu bersifat verbalistik (dalam bentuk lisan atau tulisan belaka). (b) Mengatasi keterbatasan waktu, ruang dan keterbatasan indera, seperti misalnya: (1) Objek yang besar bisa digantikan dengan model, realita, film bingkai, film, atau gambar. (2) Objek yang kecil dibantu dengan gambar, permodelan proyektor mikro, film bingkai, atau film. (3) Gerak yang terlalu lambat atau terlalu cepat, dapat dibantu dengan high speed photography atau timelapse. (4) Peristiwa yang terjadi dimasa lampau dapat ditampilkan kembali melalui video, rekaman film, film bingkai, foto ataupun secara verbal. (5) Objek yang kompleks dapat disajikan dengan mengan permodelan, diagram, dan lain sebagainya. (6) Konsep yang terlalu luas (gempa bumi, iklim, dan lain sebagainya) dapat divisualisasikan dalam bentuk film, grafik, dan lain sebagainya.

Penggunaan media pembelajaran secara tepat serta bervariasi dapat mengatasi sikap pasif peserta didik. Dalam hal ini media pembelajaran berguna untuk: (1) Menimbulkan minat belajar. (2) Memungkinkan terjadinya interaksi yang lebih langsung antara peserta didik dengan lingkungan dan kenyataan. (3) Memungkinkan peserta didik belajar secara individu menurut kemampuan dan minatnya.Dengan sifat yang berbeda pada setiap siswa ditambah lagi dengan lingkungan dan pengalaman yang berbeda, sedangkan kurikulum dan materi pendidikan ditentukan sama untuk setiap siswa, maka guru akan mengalami amat banyak kesulitan apabila semua itu harus diatasi sendiri. Hal ini akan lebih sulit lagi bila latar belakang lingkungan siswa dengan guru juga berbeda. Masalah ini dapat diatasi dengan media pembelajaran, yaitu dengan kemampuannya dalam: (1) Memberi rangsang yang sama. (2) Menyamakan pengalaman. (3) Menumbuhkan persepsi yang sama.

Lebih lanjut Rusman (2012) menjelaskan media pembelajaran dalam proses pembelajaran memiliki fungsi sebagai berikut: (1) Pembelajaran lebih menarik perhatian siswa sehingga dapat menimbulkan motivasi belajar. (2) Siswa akan lebih jelas memaknai materi pembelajaran karena pesan yang disampaikan lebih jelas, sehingga memungkinkan siswa menguasai tujuan pembelajaran dengan lebih baik. (3) Akan lebih banyak tersedia variasi metode pembelajaran, tidak hanya komunikasi verbal melalui penuturan kata oleh guru, sehingga siswa tidak merasa bosan dan guru tidak kehabisan tenaga, apalagi bila guru harus mengajar untuk banyak jam pelajaran. (4) Siswa akan lebih banyak melakukan kegiatan belajar, karena tidak hanya mendengarkan uraian guru, namun juga aktivitas lain seperti melakukan, mengamati, mendemonstrasikan, mempraktikan, dan lain sebagainya.

Berdasarkan beberapa uraian di atas dapat disimpulkan bahwa manfaat media pembelajaran pada dasarnya adalah memperjelas penyampaian pesan materi pembelajaran sehingga dapat meningkatkan perhatian dan interaksi siswa serta dapat menyamakan persepsi 
siswa. Disamping itu manfaat media pembelajaran dapat mempermudah guru dalam menyampaikan pesan pembelajaran, namun seberapa besar pun manfaat media pembelajaran tidak akan bisa menggantikan guru sepenuhnya.Fungsi media pembelajaran dalam kegiatan pembelajaran amat penting dalam meningkatkan kualitas kegiatan pembelajaran terutama membantu siswa dalam belajar. Dua unsur yang sangat penting dalam kegiatan pembelajaran yaitu metode dan media pembelajaran. Kedua hal tersebut akan saling berkaitan satu sama lain. Penentuan suatu metode akan menentukan media pembelajaran yang tepat untuk digunakan dalam kegiatan pembelajaran tersebut, media pembelajaran tidak dapat begitu saja digunakan dalam kegiatan pembelajaran, perlu dilakukan analisis terlebih dahulu sebelum media pembelajaran digunakan dalam kegiatan pembelajaran.Penggunaan media dalam kegiatan pembelajaran memang sangat disarankan, tetapi dalam penggunaannya tidak semua media pembelajaran baik. Sasaran didik, ketersediaan sarana, mutu teknis, konteks penggunaan, waktu, biaya, karakteristik media yang bersangkutan, dan tujuan pembelajaran menjadi hal-hal yang harus dipertimbangkan dalam penentuan sebuah media pembelajaran. Penggunaan media yang tepat akan dapat menunjang keberhasilan dalam proses pembelajaran. Sebaliknya, penggunaan media yang tidak tepat hanya akan hamburkan biaya, waktu dan tenaga, terlebih bagi tingkat ketercapaian tujuan pembelajaran akan jauh dari apa yang diharapkan. Sekolah sebagai salah satu sarana pembelajaran, harus dapat menyediakan media yang tepat untuk menunjang kegiatan belajar mengajar agar siswa tidak jenuh dalam menerima pembelajaran di kelas dan pembelajaran berlangsung dengan efektif. Salah satu cara untuk mengatasi kejenuhan belajar tersebut adalah dengan penggunaan media pembelajaran, termasuk didalamnya dengan pemanfaatan teknologi informasi. Pemanfaatan teknologi informasi sebagai media pembelajaran dapat dilakukan melalui pemanfaatan telefon genggam atau komputer sebagai media interaktif. Diharapkan dengan pemanfaatan media tersebut dapat merangsang perasaan, pikiran, minat, serta perhatian peserta didik.

Adapun tujuan penelitian ini adalah (1) untuk mengetahui apakah penggunaan multimedia i-spring dapat meningkatkan hasil belajar siswa dalam pembelajaran Pendidikan Agama Islam, (2) untuk mengetahui apakah penggunaan media presentasi power point dapat meningkatkan hasil belajar siswa dalam pembelajaran Pendidikan Agama Islam, dan (3) untuk menemukan perbedaan hasil belajar siswa antara yang menggunakan multimedia ispring dengan yang menggunakan multimedia power point pada pembelajaran Pendidikan Agama Islam.

\section{METODE PENELITIAN}

Jenis penelitian ini adalah eksperimen kuasi terhadap du akelas yang berbeda. Penelitian ini merupakan penelitian eksperimen dengan pendekatan kuantitatif, bentuk eksperimen yang digunakan adalah dengan menggunakan bentuk quasi experimental design yang merupakan desain yang mempunyai kelompok control tetapi tidak dapat berfungsi sepenuhnya untuk mengontrol variable-variabel luar yang mempengaruhi pelaksanaan eksperimen (Sugiyono, 2019). Penelitian yang dilakukan oleh peneliti saat ini diharapkan dapat memberikan gambaran secara mendalam mengenai efektivitas penggunaan multimedia interaktif $i$-spring dan power point dalam upaya meningkatkan hasil belajar siswa.

Tempat penelitian di SDN Jambu dan SDN Kampung Baru di Kecamatan Bajo Kabupaten Luwu, Sulawesi-Selatan. Kelas pertama yaitu kelas IV SDN Jambu diberikan perlakuan dengan menggunakan multimedia i-spring dalam pembelajaran Pendidikan Agama Islam dengan materi tata cara shalat. Kelas IV yang kedua adalah SDN Kampung Baru diperlakukan dengan bantuan power point dan materi yang sama. Sebelum pelaksanaan penelitian, terlebih dahulu diberikan pretest kepada kedua kelas tersebut, dengan tujuan untuk mengetahui apakah kedua kelas tersebut homogen atau tidak homogen. Apabila homogen maka pada akhir penelitian langsung dibandingkan hasil post-test kedua kelas tersebut untuk 
Irwanto

IMPLEMENTASI MULTIMEDIA I-SPRING DENGAN POWERPOINT UNTUK

MENINGKATKAN HASIL BELAJAR PADA PEMBELAJARAN SALAT UNTUK MATA

PELAJARAN PENDIDIKAN AGAMA ISLAM

menemukan perbedaan peningkatan hasil belajar keduanya. Jika sebaliknya, tidak homogen, maka harus dilakukan pengujian terhadap peningkatan hasil belajar sebelum dan sesudah perlakuan (gain) dari kedua kelas tersebut.

Populasi dalam sampel penelitian ini adalah siswa kelas IV SDN Jambu dengan sampel 26 orang dan SDN Kampung Baru dengan sampel 26 orang. Sekolah pertama yaitu kelas IV SDN Jambu diberikan perlakuan dengan menggunakan multimedia i-spring dalam pembelajaran Pendidikan Agama Islam, serta kelas IV yang kedua diberikan perlakuan dengan menggunakan power point dalam pembelajaran Pendidikan Agama Islam mengenai tata cara shalat.

Teknik yang digunakan untuk memperoleh data, harus digunakan instrument yang dapat menunjang dan dapat memperoleh data dari permasalahan yang diteliti. Instrument yang yang diberikan adalah soal pre-test dan post-test yang merupakan tes pilihan ganda (PG) berjumlah 30 butir soal dengan tujuan untuk mengetahui hasil belajar siswa terhadap treatment yang diberikan. Teknik pengumpulan data dilakukan berupa pengerjaan tes setelah pemberian perlakuan (treatment) atau dengan post-test.

Prosedur dan tahapan-tahapan dalam penelitian ini adalah (1) studi pendahuluan, (2) perumusan masalah, (3) studi literatur, (4) pengembangan instrument penelitian bersamaan dengan penyusunan multimedia interaktif berbantuan i-spring dan power point yang digunakan sebagai media pembelajaran, (5) pelaksanaan test awal (pre-test), (6) pelaksanaan penelitian, (7) pelaksanaan tes akhir (post-test), (8) pengolahan dan analisis hasil tes akhir, (9) pembahasan hasil penelitian dan (10) pengambilan kesimpulan dan pengajuan rekomendasi.

Teknik analisis data yang digunakan dalam penelitian ini adalah menguji kesamaan dua rata-rata antara kelompok eksperimen dengan kelompok kontrol. Untuk menjawab hipotesis yang telah diajukan, ada beberapa langkah-langkah pengolahan secara statistik. Pengujian yang dilakukan yaitu dengan cara menguji kesamaan dua rata-rata dengan uji t satu pihak dan sebelum ke pengujian harus dilakukan terlebih dahulu pengujian normalitas datanya.

\section{HASIL PENELITIAN DAN PEMBAHASAN}

Dari hasil penelitian menyatakan bahwa hasil pretest menunjukkan tidak ada siswa yang mencapai kriteria ketuntasan minimal (KKM) pada pembelajaran praktik shalat pada mata pelajaran Pendidikan agama Islam yaitu 70 . Rata-rata yang diperoleh 60, masi rendah dari KKM dan nilai tertinggi 65 dan nilai yang terendah 30 tersebut. Pada hasil posttest berdasarkan hasil pengolahan SPSS didapat 20 siswa atau sebanyak $70.9 \%$ berhasil mencapai KKM dan 6 siswa atau sebanyak $29.1 \%$ belum mencapai KKM.

Hasil penelitian diperoleh data skor hasil pretes, posttest, dan peningkatan hasil belajar kelas eksperimen. Setelah dilakukan suatu analisis terhadap hasil belajar siswa baik sebelum maupun setelah dilakukan suatu proses pembelajaran yang berdasarkan media ispring selanjutnya untuk mengetahui peningkatan hasil belajar dilakukan dengan menghitung nilai gain ternormalisasi tersebut.Dari hasil pengolahan SPSS terdapat 7 siswa atau sebanyak 26.9\% mengalami peningkatan dengan kategori tinggi dan 16 siswa sebanyak $61.5 \%$ mengalami peningkatan kategori sedang dan sebanyak 3 siswa atau $11.5 \%$ mengalami peningkatan kategori rendah. Jadi sangat jelas bahwa adanya perbedaan nilai yang didapat siswa pada saat mengikuti pretest dan posttest tersebut. Data-data ini didapat dari hasil pengolahan data program SPSS versi 18 berdasarkan perhitungan nilai rata-rata tersebut. Untuk pengujian nilai rata-rata hasil belajar pada kelompok eksperimen dapat dilihat pada Tabel 1 berikut. 
Tabel 1. Nilai Rata-rata Hasil Belajar Kelompok Eksperimen

\begin{tabular}{lllll}
\hline Jenis Test & Mean & $\mathbf{N}$ & Std. Deviation & Std. Error Mean \\
\hline Pretest & 37.23 & 26 & 12.637 & 2.478 \\
\hline Posttest & 73.23 & 26 & 12.938 & 2.537 \\
\hline
\end{tabular}

Berdasarkan Tabel 1 di atas, dapat diketahui bahwa adanya peningkatan nilai siswa kelas eksperimen dari nilai rata-rata sebelum menggunakan i-spring 37.23 mengalami peningkatan menjadi 73.23. Kemudian untuk pengujian hipotesis dilakukan dengan pengujian sampel berpasangan (paired samples test) dengan menggunakan software SPSS versi 18 untuk mengetahui ada atau tidak ada peningkatan hasil belajar siswa yang diambil dari pretest dan nilai posttest. Dengan demikian dapat disimpulkan bahwa terdapat peningkatan hasil belajar siswa kelas IV SDN Jambu pada pembelajaran tata cara pelaksanaan shalat lima waktu menggunakan interaktif berdasarkan i-spring.

Untuk pembelajaran pada kelompok control dengan power point, hasil pretest menunjukkan tidak ada siswa yang mencapai KKM pada pembelajaran tata cara pelaksanaan shalat lima waktu dengan 70. Rata-rata yang diperoleh 48, rendah dari KKM dan nilai tertinggi 65 dan nilai terendah 31. Hasil posttes juga diperoleh dengan bantuan perhitungan software SPSS 18, maka diperoleh hasil seperti pada Tabel 2 di bawah ini.

Tabel 2. Ketuntasan Kelompok Kontrol

\begin{tabular}{lllll}
\hline & Frequency & Percent & Valid Percent & Cumulative Percent \\
\hline Valid Tuntas & 20 & 76.9 & 76.9 & 76.9 \\
\hline Tidak Tuntas & 6 & 23.1 & 23.1 & 100.0 \\
\hline Total & 26 & 100.0 & 100.0 & \\
\hline
\end{tabular}

Berdasarkan hasil pada Tabel 2 di atas terdapat 20 siswa atau sebanyak $76.0 \%$ berhasil mencapai KKM serta ada 6 siswa dengan $23.1 \%$ belum mencapai KKM atau belum tuntas. Setelah dilakukan analisis terhadap hasil belajar siswa baik sebelum maupun setelah dilakukan proses pembelajaran yang berdasarkan power point selanjutnya belajar dilakukan dengan menghitung nilai gain ternormalisasi. Maka diperoleh hasil, seperti pada Tabel 3 di bawah ini.

Tabel 3. Nilai Gain Kelompok Kontrol

\begin{tabular}{lllll}
\hline & Frequency & Percent & Valid Percent & Cumulative Percent \\
\hline Valid Tinggi & 3 & 11.5 & 11.5 & 11.5 \\
\hline Sedang & 18 & 69.2 & 69.2 & 80.8 \\
\hline Rendah & 5 & 19.2 & 19.2 & 100.0 \\
\hline Total & 26 & 100.0 & 100.0 & \\
\hline
\end{tabular}

Berdasarkan hasil pengolahan data seperti pada Tabel 3 di atas didapatkan bahwa terdapat 3 siswa atau $11.5 \%$ mengalami peningkatan dengan kategori tinggi, 18 siswa atau $69.2 \%$ mengalami peningkatan kategori sedang dan 5 siswa atau sebanyak $19.2 \%$ mengalami peningkatan rendah. Maka didapat suatu peningkatan nilai pretest dan posttest, namun untuk mengetahui lebih jelasnya maka diuji berdasarkan statistik dengan menggunakan software SPSS 18 berdasarkan nilai rata-rata yang didapat. Untuk mengetahui nilai rata-rata hasil belajar pada kelompok kontrol dapat di lihat pada Tabel 4 berikut. 
Irwanto

IMPLEMENTASI MULTIMEDIA I-SPRING DENGAN POWERPOINT UNTUK

MENINGKATKAN HASIL BELAJAR PADA PEMBELAJARAN SALAT UNTUK MATA

PELAJARAN PENDIDIKAN AGAMA ISLAM

Tabel 4. Nilai Rata-rata Hasil Belajar Mengalami Peningkatan Pada Kelompok Kontrol

\begin{tabular}{|l|l|l|l|l|}
\hline & Mean & N & Std. Deviation & Std. Error Mean \\
\hline Pair Pretest & 42.62 & 26 & 12.024 & 2.358 \\
\hline Posttest & 69.85 & 26 & 10.924 & 2.142 \\
\hline
\end{tabular}

Berdasarkan Tabel 4 di atas memperlihatkan bahwa adanya peningkatan nilai siswa pada kelas kontrol dari nilai rata-rata sebelumnya menggunakan power point 42.62 mengalami peningkatan menjadi nilai rata-rata 69.85. untuk menguji hipotesis maka dilakukan pengujian sampel berpasangan dengan software SPSS versi 18, mengenai ada atau tidak ada peningkatan hasil belajar siswa yang diambil dari nilai pretest dan posttest.

Pengujian sampel berpasangan menunjukkan bahwa nilai sig. (2-tailed) adalah 0.000 lebih kecil dari nilai $\alpha=0.05$ karena nilai sig. (2-tailed) < maka Ho di tolak dan Ha di terima (Sugiyono, 2019). Dengan demikian bahwa terdapat peningkatan hasil belajar siswa kelas IV SD Negeri Jambu pada pembelajaran praktik shalat pada mata pelajaran Pendidikan Agama Islam menggunakan media interaktif berdasarkan power point. Pengujian normalitas untuk kelompok eksperimen berdistribusi normal sedangkan uji normalitas untuk kelompok kontrol berdistribusi normal. Hasil perhitungan pada uji homogenitas didapatkan bahwa nilai $\alpha=$ $0.05 \%$ yaitu 0.877. Dengan demikian menunjukkan bahwa Ha diterima bahwa kemampuan awal pada kelompok eksperimen dan kelompok kontrol adalah homogen.

Pengujian hipotesis yang didapat yaitu nilai sig. pada kolom equal variances assumed yaitu 0.448 , nilai ini lebih besar dari nilai $\alpha$ yang digunakan yaitu 0.05 . Maka dapat disimpulkan bahwa tidak terdapat perbedaan hasil belajar siswa antara kelompok eksperimen yang menggunakan i-spring dengan kelompok kontrolyang menggunakan power point pada materi praktek shalat pada mata pelajaran Pendidikan Agama Islam.

Perbedaan hasil belajar antara kelompok eksperimen yang menggunakan i-spring dengan kelompok kontrol yang menggunakan power point mengalami peningkatan hasil belajar pada materi praktik shalat untuk mata pelajaran Pendidikan Agama Islam. Tetapi ratarata nilai yang diperoleh kelompok eksperimen yang menggunakan i-spring lebih tinggi dibandingkan dengan kelompok kontrol yang menggunakan power point. Kemudian berdasarkan hasil analisis data statistik, ternyata tidak terdapat perbedaan hasil belajar antara kelompok eksperimen yang menggunakan i-spring dengan kelompok kontrol yang menggunakan power point pada materi praktik shalat pada mata pelajaran Pendidikan Agama Islam.

Perubahan perilaku tersebut disebabkan karena siswa mencapai penguasaan atas sejumlah bahan yang diberikan dalam proses belajar mengajar dan menerima pengalaman belajar yang berbeda dengan menggunakan media presentasi (Suyono, 2012) dan proses pembelajaran telah berlangsung secara efektif. Surya (2004) mengatakan bahwa perubahan individuyang memperoleh perilaku individu yang baru, menetap, fungsional, positif, disadari dan sebagainya. Perubahan perilaku sebagai hasil pembelajaran adalah perilaku secara keseluruhan yang mencakup aspek kognitif, afektif, konatif dan motorik. Menurut Arsyad (2017) menyatakan bahwa media merupakan alat yang menyampaikan atau mengantarkan pesan-pesan pembelajaran. Media pembelajaran merupakan seperangkat alat bantu atau pelengkap yang digunakan oleh guru atau pendidik dalam rangka berkomunikasi dengan siswa.

Hasil tersebut membuktikan bahwa penggunaan teknologi media i-spring dan power point dalam pembelajaran Pendidikan Agama Islam dapat meningkatkan hasil belajar siswa dan memberikan beberapa keuntungan yang positif. Dari hasil penelitian di atas menunjukkan bahwa penggunaan i-spring dan power point dalam pembelajaran yang memenuhi prinsip- 
prinsip penggunaan media dapat meningkatkan hasil belajar karena prinsipnya penggunaan media dalam pembelajaran: (1) mengarahkan untuk mempermudah siswa belajar dalam upaya meningkatkan hasil belajar untuk mata pelajaran Agama, (2) harus sesuai dengan materi pembelajaran, (3) harus menyesuaikan dengan minat, kebutuhan serta kondisi siswa, (4) harus memperhatikan efektivitas dan efisien, dan (5) harus sesuai dengan kemampuan guru dalam mengoperasikannya teknologi tersebut.

\section{SIMPULAN DAN SARAN}

Berdasarkan hasil analisis data dan pengujian hipotesis yang telah diperoleh dari hasil pretest dan posttest pada pembelajaran Pendidikan Agama Islam di kelas IV SD Negeri Jambu dan Kampung Baru, maka dapat diambil kesimpulan bahwa: (a) dalam pembelajaran dengan i-spring sebanyak $80.8 \%$ berhasil mencapai KKM dan $19.2 \%$ belum mencapai KKM serta nilai rata-ratanya mencapai 73.23 dengan nilai tertinggi 94 dan nilai terendah 44 . (b) nilai rata-rata yang diperoleh pada kelompok eksperimen hanya 42.62 dengan nilai tertinggi dan nilai terendah 24 , dengan melaksanakan pembelajaran power point maka nilai rata-rata diperoleh nilai kelas ini pun meningkat yaitu mencapai rata-rata 69.85 dengan nilai tertinggi 88 dan nilai terendah 40. (c) tidak terdapat perbedaan hasil belajar siswa antara kelompok eksperimen yang menggunakan i-spring dengan kelompok kontrol yang menggunakan power point.

Dalam penelitian ini telah terbukti adanya peningkatan hasil belajar, tetapi ini hanya terbatas pada tingkat SD serta hanya pada mata pelajaran Pendidikan Agama Islam. Tidak menutup kemungkinan penelitian-penelitian berikutnya yang lebih luas dan mendalam bisa dikembangkan di tingkat yang lebih tinggi lagi. Hal tersebut dimaksudkan agar terjadi pengembanan lebih lanjut demi perbaikan dan peningkatan pembelajaran yang lebih baik lagi. 
Irwanto

IMPLEMENTASI MULTIMEDIA I-SPRING DENGAN POWERPOINT UNTUK

MENINGKATKAN HASIL BELAJAR PADA PEMBELAJARAN SALAT UNTUK MATA

PELAJARAN PENDIDIKAN AGAMA ISLAM

\section{DAFTAR PUSTAKA}

Arsyad, A. (2017). Media pembelajaran. Jakarta: PT. Raja Grafindo Persada.

Daryanto. (2010). Belajar dan mengajar. Bandung: Yrama Widya.

Depdiknas. (2003). Undang-Undang Republik Indonesia Nomor 20 Tahun 2003 Tentang Sistem Pendidikan Nasional.

Dimyati \& Mudjiono. (2006). Belajar dan pembelajaran. Jakarta: PT. Asdi Mahasatya.

Hamalik, O. (2011). Kurikulum dan pembelajaran. Jakarta: Bumi Aksara.

Munadi, Y. (2013). Media pembelajaran (sebuah pendekatan baru). Jakarta: Referensi.

Rahyubi, H. (2016). Teori-teori belajar dan aplikasi pembelajaran motorik. Majalengka: Referens.

Rusman. (2012). Belajar dan pembelajaran berbasis komputer. Bandung: Alfabeta.

Sadiman, Arief. (2010). Media pendidikan. Jakarta: Rajawali Pers.

Sagala, S. (2012). Konsep dan makna pembelajaran. Bandung: Alfabeta.

Siregar, E., \& Nara, H. (2010). Teori belajar dan pembelajaran. Bogor: Ghalia Indonesia.

Sudjana, N. (2016). Penilaian hasil proses belajar mengajar. Bandung: PT. Remaja Rosdakarya.

Sugiyono. (2019). Metode penelitian pendidikan, pendekatan kuantitatif, kualitatif, dan $r \& d$. Bandung: Alfabeta.

Surya, Mohamad. (2004). Psikologi pembelajaran dan pengajaran. Bandung: Pustaka Bani Quraisy.

Susilana, R., \& Riyana, C. (2008). Media pembelajaran. Bandung: CV Wacana Prima.

Suyono \& Hariyanto. (2012). Belajar dan pembelajaran (teori dan konsep dasar). Bandung: Remaja Rosda Karya.

Suyono \& Hariyanto. (2016). Belajar dan pembelajaran. Bandung: Remaja Rosdakarya Offset.

Yamin, M. (2015). Teori dan metode pembelajaran. Malang: Madani. 